Article

\title{
Establishment of an Aseptic Culture System and Analysis of the Effective Growth Conditions for Eleocharis acicularis Ramets for Use in Phytoremediation
}

\author{
Yasushi Sato ${ }^{1, *}$, Shinpei Goto ${ }^{2}$, Shoya Teraoka ${ }^{2}$, Katsuya Takagaki ${ }^{2}$, Akinari Takehara ${ }^{1}$, \\ Sakae Sano $^{3}$ and Masayuki Sakakibara ${ }^{1,4}$ \\ 1 Graduate School of Science and Engineering, Ehime University, Matsuyama 790-8577, Japan; \\ 1411akinari@gmail.com (A.T.); sakakibara.masayuki.mb@ehime-u.ac.jp (M.S.) \\ 2 Faculty of Science, Ehime University, Matsuyama 790-8577, Japan; spa86zx9@gmail.com (S.G.); \\ trky4408st@gmail.com (S.T.); katsuya.takagaki@gmail.com (K.T.) \\ 3 Faculty of Education, Ehime University, Matsuyama 790-8577, Japan; sano@ehime-u.ac.jp \\ 4 Faculty of Collaborative Regional Innovation, Ehime University, Matsuyama 790-8577, Japan \\ * Correspondence: ysato@sci.ehime-u.ac.jp; Tel.: +81-89-927-9633
}

Academic Editor: Yu-Pin Lin

Received: 7 April 2017; Accepted: 30 May 2017; Published: 3 June 2017

\begin{abstract}
Eleocharis acicularis, an aquatic macrophyte of the Cyperaceae family, has been shown to accumulate multiple heavy metals and has great potential for use in the phytoremediation of contaminated soil and water. To investigate the mechanism of accumulation of heavy metals in E. acicularis while excluding biotic and abiotic environmental effects and to acquire homogenous and sufficient populations of E. acicularis, we established an aseptic culture system and analyzed the applicability of this species for phytoremediation. Young ramet bases and stolon tips of E. acicularis grown in the field were sterilized, cultured, and established in an aseptic culture system, and the effective growth conditions of isolated ramets were determined. Isolated ramets grew remarkably well in a medium of $\mathrm{pH} 4.8$ to 5.7 with $0.25 \mathrm{mg} / \mathrm{L}$ kinetin as a plant hormone. Furthermore, capacity for the accumulation of heavy metals was examined using E. acicularis subcultured with or without $\mathrm{Si}$. Aseptically cultured E. acicularis showed a sufficient capacity for Cs and $\mathrm{Zn}$ accumulation and exceeded the criteria for hyperaccumulator plants in accumulating $\mathrm{Pb}, \mathrm{Cd}$, and In regardless of the addition or not of $\mathrm{Si}$ during its subculture. The aseptic culture of E. acicularis enhances its capacity for the accumulation of heavy metals and its applicability for phytoremediation.
\end{abstract}

Keywords: aquatic macrophyte; heavy metals; plant hormones; primary culture and subculture

\section{Introduction}

Pollution by heavy metals and metalloids is a serious global environmental problem. Various industrial activities, such as mining, urban sewage, and smelters, are known to be sources of heavy metals and metalloids that cause environmental pollution. Heavy metals and metalloids accumulate in soil and water and pose a risk to human health and the health of other living organisms. Some of these elements accumulate in the tissues of living organisms via bioaccumulation, and their concentration in living organisms at higher trophic levels increases via biomagnification [1].

Although various physical and chemical methods have been developed for the removal of heavy metals and metalloids from contaminated substrates, almost all of these methods are expensive and require large investments [2]. By contrast, phytoremediation, a technology that involves the use of 
plants to remove influences of pollutants from the environment, is considered a cost-effective and environmentally friendly technology for removing heavy metals and metalloids [3].

The aquatic macrophyte Eleocharis acicularis (L.) Roem. \& Schult. (abbreviated to E. acicularis), which belongs to the Cyperaceae family and lives in damp ground, rivers, and ponds, was reported to accumulate multiple heavy metals effectively, including $\mathrm{Cu}, \mathrm{In}, \mathrm{Ag}, \mathrm{Cd}$, and $\mathrm{Pb}$ from mine tailings and drainage in laboratory and field experiments. This species is a candidate plant for the phytoremediation of water and soils contaminated by heavy metals and metalloids [4-7]. Furthermore, it was reported that native E. acicularis in Fukushima Prefecture had accumulated up to $2400 \mathrm{~Bq} / \mathrm{kg}$ wet weight of radiogenic Cs from a paddy field contaminated with ${ }^{134} \mathrm{Cs}$ and ${ }^{137} \mathrm{Cs}$ due to the Fukushima Daiichi nuclear disaster [8]. Thus, E. acicularis showed great potential for use in the phytoremediation of soil and water contaminated by radiogenic $C s$ in the nuclear disaster area.

Laboratory and field experiments using E. acicularis have been carried out with native and cultivated E. acicularis. However, the acquisition of homogenous and sufficient populations of the plant of interest is challenging because native plants are limited and are not always homogenous. Moreover, their collection and cultivation depend on the area, season, and weather. The ability of plants to accumulate heavy metals is not always stable because they are affected by various environmental factors, including abiotic factors such as nutrients and biotic factors such as microscopic algae and bacteria $[9,10]$. For an accurate estimation of the capacity for the accumulation of heavy metals by the plant itself, the influence of various abiotic and biotic environments should be removed. Such conditions also enable us to specifically compare the abilities of different plant species to accumulate heavy metals for use in phytoremediation. For this purpose, the establishment of an aseptic culture system for a plant is the most efficient method. In addition, the analysis of effective growth conditions in aseptic culture conditions is beneficial for future investigations and applications.

Based on the research needs described above, the purpose of this study was to (1) establish aseptic culture conditions for E. acicularis, (2) analyze the effective growth conditions for young E. acicularis ramets with a focus on the plant hormones and $\mathrm{pH}$ of the medium, (3) show the capacity of aseptically cultured E. acicularis to accumulate heavy metals, and (4) examine whether silicon addition during subculture of E. acicularis is effective for heavy metal accumulation.

Consequently, the aseptic culture conditions for E. acicularis were established. Using aseptically cultured E. acicularis, the appropriate kinetin concentration and the range of $\mathrm{pH}$ of the culture medium for the growth of single young ramets of E. acicularis were determined. Furthermore, the capacity of aseptically cultured E. acicularis with or without the addition of $\mathrm{Si}$ for the accumulation of heavy metals, including $\mathrm{Cs}, \mathrm{Zn}, \mathrm{Pb}, \mathrm{Cd}$, and In, was compared with that of native E. acicularis. The results indicate the potential for generating superior E. acicularis plants for use in phytoremediation using an aseptic culture system.

\section{Materials and Methods}

\subsection{Plant Material and Aseptic Culture Conditions}

E. acicularis used in the primary culture was collected from a clump in an agricultural irrigation ditch in northwestern Shikoku, Japan. The plants were washed thoroughly with tap water followed by deionized water (DIW) to remove sediments. Stolon tips or young ramets developing near the stolon tips were excised 2 to $3 \mathrm{~mm}$ from each outthrust stolon or stem; sterilized with $0.15 \%, 0.45 \%$, or $0.75 \% \mathrm{NaClO}$ (available chlorine percentage) for $10 \mathrm{~min}$; and washed with sterilized DIW five times. The explants were aseptically placed on $3 \mathrm{~mL}$ of solid medium in test tubes capped with aluminum foil and cultured at $22{ }^{\circ} \mathrm{C}$ under the continuous fluorescent light condition of $50-55 \mu \mathrm{mol} / \mathrm{m}^{2} / \mathrm{s}$. The solid medium was Murashige and Skoog [11] containing 0.25\% gellan gum (Wako Pure Chemical Industries, Tokyo, Japan), $1 \%$ sucrose, and $0.05 \%$ 2-morpholinoethanesulfonic acid- $\mathrm{KOH}$ (pH 5.7). After more than one month of culture, the growing ramets were placed into $100 \mathrm{~mL}$ of liquid medium, similar to solid medium but without gellan gum, in a plastic container (length, width, height $80 \mathrm{~mm}$ each; PLANTAN, 
Shibata Scientific Technology, Saitama, Japan). For the culture in the plastic container, the cap without the inner rubber seal was loosened by a quarter and the gap between the cap and the container was doubly sealed with Micropore Surgical Tape (1530-0, 3M Japan, Tokyo, Japan). After sufficient growth under the above light and temperature conditions, the plant community was cut into two with a scalpel and cultured individually in $100 \mathrm{~mL}$ liquid medium. E. acicularis cultures were maintained aseptically by subculturing every 3 weeks.

\subsection{Analysis of the Effect of Plant Hormones and pH Conditions on the Growth of Young Ramets of E. acicularis}

From growing stolons of aseptically cultured E. acicularis, young ramets with a length of 3-4 cm of terrestrial stems were excised while retaining $5 \mathrm{~mm}$ of outthrust stolons on both sides. Three excised ramets were placed into $15 \mathrm{~mL}$ of liquid medium supplied with plant hormones and adjusted $\mathrm{pH}$ in flat-bottom glass tubes (diameter $30 \mathrm{~mm}$, height $120 \mathrm{~mm}$; AGC Techno Glass, Shizuoka, Japan) with plastic caps (AGC Techno Glass) and cultured under the abovementioned light and temperature conditions. For plant hormones, 10,000 times the concentration of plant hormones dissolved in dimethylsulfoxide (kinetin as cytokinin: $0,1,2.5,5,10$, or $25 \mathrm{mg} / \mathrm{mL}$; gibberellic acid-3 (GA 3 ) as gibberellin: 0, 0.1, 1, or $10 \mathrm{mg} / \mathrm{mL}$; 1-naphthaleneacetic acid (NAA) as auxin: $0,0.1,1$, or $10 \mathrm{mg} / \mathrm{mL}$ ) were added after autoclaving the liquid medium.

\subsection{Preparation of E. acicularis Harboring Phytoliths}

For the preparation of E. acicularis harboring phytoliths, autoclaved liquid medium was supplemented with $0.1 \mathrm{mM}, 0.4 \mathrm{mM}$, or $1 \mathrm{mM} \mathrm{Na}_{2} \mathrm{SiO}_{3}$ by adding 1000-fold concentration of stock solution (0.1 M, $0.4 \mathrm{M}$, or $1 \mathrm{M}$ ) sterilized with a $0.22 \mu \mathrm{m}$ filter (Millex-GP, Merck Millipore, Damstadt, Germany). The $\mathrm{pH}$ of the medium with $\mathrm{Na}_{2} \mathrm{SiO}_{3}$ was then adjusted with $\mathrm{HCl}$ by adding stock solution $(0.2 \mathrm{M}, 0.8 \mathrm{M}$, or $2 \mathrm{M})$ sterilized with a $0.22 \mu \mathrm{m}$ filter (Millex-GP). The volume for addition of the stock solution of $\mathrm{HCl}$ was determined beforehand by titration of the medium supplied with $\mathrm{Na}_{2} \mathrm{SiO}_{3}$. For the preparation of the plants subcultured with $0.1 \mathrm{mM}$ Si for for analysis of Cs contents, plant communities were subcultured in the medium containing $0.4 \mathrm{mM}$ Si for 3 weeks. After that, the plants were subcultured weekly in the medium containing $0.1 \mathrm{mM}$ Si for 4 weeks. For the experiment using the plants subcultured with $1 \mathrm{mM} \mathrm{Si}$, the plant communities subcultured every 3 weeks in the medium containing $0.1 \mathrm{mM}$ Si for 6 months were further subcultured every 3 weeks in the medium containing $1 \mathrm{mM}$ Si for 6 months for analyses of the contents of Si and Cs or 11 months for analyses of the contents of $\mathrm{Zn}, \mathrm{Pb}, \mathrm{Cd}$, and In by inductively coupled plasma-atomic emission spectroscopy (ICP-AES).

\subsection{Staining of Phytoliths}

Phytoliths in E. acicularis were stained with methyl red according to the method of [12] using toluene instead of benzene.

\subsection{Heavy Metal Preparation}

Stock solutions of $4.8 \mathrm{mg} / \mathrm{mL} \mathrm{Cs}\left({ }^{133} \mathrm{CsCl}\right.$ solution of stable isotope), $1.0 \mathrm{mg} / \mathrm{mL} \mathrm{Zn}\left(\mathrm{ZnSO}_{4}\right.$ solution), $4.0 \mathrm{mg} / \mathrm{mL} \mathrm{Pb}$ ( $\mathrm{PbCl}_{2}$ solution), $4.0 \mathrm{mg} / \mathrm{mL} \mathrm{Cd}\left(\mathrm{CdCl}_{2}\right.$ solution), and $4.0 \mathrm{mg} / \mathrm{mL} \mathrm{In}\left(\mathrm{InCl}_{3}\right.$ solution) were sterilized using a $0.22 \mu \mathrm{m}$ filter (Millex-GP), added to sterilized DIW, and used to prepare the fundamental solution of $4.8 \mathrm{mg} / \mathrm{L} \mathrm{Cs}, 4.1 \mathrm{mg} / \mathrm{L} \mathrm{Zn}, 41 \mathrm{mg} / \mathrm{L} \mathrm{Pb}, 47 \mathrm{mg} / \mathrm{L} \mathrm{Cd}$, and $38 \mathrm{mg} / \mathrm{L}$ In.

\subsection{Experimental Setup and Sampling for Analysis of Heavy Metal Accumulation in E. acicularis}

The whole plants cultured aseptically were washed thoroughly with DIW to remove the medium, and samples of $1.0 \mathrm{~g}$ fresh weight were placed in plastic containers (PLANTAN) with $100 \mathrm{~mL}$ of fundamental solution (DIW supplied with heavy metals). These samples were cultured at $22{ }^{\circ} \mathrm{C}$ under a continuous fluorescent light condition of $40-50 \mu \mathrm{mol} / \mathrm{m}^{2} / \mathrm{s}$ with shaking on a shaker $(80 \mathrm{rpm}, \mathrm{NR}-10$, 
TAITEC, Saitama, Japan). For analysis of Cs removal from the fundamental solutions at 0, 1, 4, 7, 10, 14, and 28 day(s) of culture, $50 \mu \mathrm{L}$ was collected aseptically and used for inductively coupled plasma-mass spectrometry (ICP-MS). For analyses of $\mathrm{Zn}, \mathrm{Cd}, \mathrm{Pb}$, and In removal at 0, 3, 7, and 14 day(s) of culture, $500 \mu \mathrm{L}$ was collected aseptically and used for ICP-AES. After 28 days of culture for Cs accumulation analysis or after 14 days of culture for $\mathrm{Zn}, \mathrm{Cd}, \mathrm{Pb}$, and In accumulation analyses, E. acicularis was harvested. For analysis of Cs contents in control samples, subcultured plants with $0.1 \mathrm{mM}$ of $\mathrm{Si}$ described above and subcultured plants without Si were harvested and used for ICP-MS. For analyses of the contents of $\mathrm{Zn}, \mathrm{Pb}, \mathrm{Cd}$, and In in control samples, subcultured plants with $0.1 \mathrm{mM}$ of Si every 3 weeks for 6 months and subcultured plants without Si were harvested and used for ICP-MS.

\subsection{Analytical Methods}

\subsubsection{Digestion of Plants for the Measurement of $\mathrm{Cs}, \mathrm{Zn}, \mathrm{Pb}, \mathrm{Cd}$, and In}

Harvested E. acicularis was washed thoroughly with DIW and dried in a ventilated oven at $80{ }^{\circ} \mathrm{C}$ for $48 \mathrm{~h}$. The dried samples were ground into a fine powder using an agate mortar. For the measurement of $\mathrm{Cs}, \mathrm{Zn}, \mathrm{Pb}, \mathrm{Cd}$, and $\mathrm{In}, 20 \mathrm{mg}$ of pulverized powder was digested in a polytetrafluoroethylene (PTFE) digestion vessel with a solution of $\mathrm{H}_{2} \mathrm{O}_{2}, \mathrm{HNO}_{3}$, and $\mathrm{HF}$ at $160{ }^{\circ} \mathrm{C}$ for $30 \mathrm{~min}$ and subsequent processing as described previously [13]. The resulting digested sample in $1.00 \mathrm{~mL}$ of $30 \% \mathrm{HNO}_{3}$ was diluted by $3 \% \mathrm{HNO}_{3}$ and used as the solution for analysis.

\subsubsection{ICP-MS Analysis}

The concentrations of $\mathrm{Cs}$ in fundamental solutions and digested plant samples and $\mathrm{Zn}, \mathrm{Pb}$, $\mathrm{Cd}$, and In in digested control samples were analyzed with an inductively coupled plasma-mass spectrometer (Varian 820-MS, Varian, Mulgrave, Australia) at the Integrated Center for Sciences, Ehime University, Japan. For ICP-MS, the linier analytical calibration curves $\left(R^{2}=0.99998\right.$ for Cs, 0.99984 for $\mathrm{Zn}, 0.99999$ for $\mathrm{Pb}, 1.00000$ for $\mathrm{Cd}$, and 0.99998 for In) were created from 0,10 , and $200 \mu \mathrm{g} / \mathrm{L}$ for Cs or 0, 5, and $200 \mu \mathrm{g} / \mathrm{L}$ for $\mathrm{Zn}, \mathrm{Pb}, \mathrm{Cd}$, and In using multi-element calibration standard 3 (PerkinElmer, Inc., Waltham, MA, USA). Rhodium standard solution (Wako Pure Chemical Industries, Ltd., Osaka, Japan) was used as the internal standard. The analytical accuracy was verified using the NIES CRM \#1 (Pepperbush), in which Cs concentration was published as $1.2 \mathrm{mg} / \mathrm{kg}$. The concentration of Cs in NIES CRM \#1 was determined as $1.28 \mathrm{mg} / \mathrm{kg}$. Fundamental solutions and digested plant samples were diluted $\sim 500$ and $\sim 250,000$ times with $3 \% \mathrm{HNO}_{3}$, respectively, and dilution factors were calculated according to the weights. The detection limits of $\mathrm{Cs}, \mathrm{Zn}, \mathrm{Pb}, \mathrm{Cd}$, and In in ICP-MS were 0.002, 0.05, $0.0006,0.0003$, and $0.0004 \mu \mathrm{g} / \mathrm{L}$, respectively. These values were sufficiently lower than heavy metal concentrations in the sample solutions used in this study.

\subsubsection{Atomic Absorption Spectrophotometry Analysis}

The concentrations of $\mathrm{Cs}$ in digested plant samples were alternatively analyzed with an atomic absorption spectrophotometer (Z-8200, Hitachi, Tokyo, Japan) after 1000 times dilution in $5.0 \mathrm{mg} / \mathrm{mL}$ $\mathrm{KNO}_{3}$. The linear analytical calibration curve $\left(\mathrm{R}^{2}=0.99546\right)$ was created from $0,0.50,1.00,2.50$, and $5.00 \mathrm{mg} / \mathrm{L}$ of $\mathrm{Cs}$ using $\mathrm{CsCl}$ in $5.0 \mathrm{mg} / \mathrm{mL} \mathrm{KNO}_{3}$. The detection limit of $\mathrm{Cs}$ with an atomic absorption spectrophotometer was $0.05 \mathrm{mg} / \mathrm{L}$. This value was sufficiently lower than Cs concentrations in the solutions of digested plant samples used in this study.

\subsubsection{ICP-AES Analysis}

The concentrations of $\mathrm{Zn}, \mathrm{Pb}, \mathrm{Cd}$, and In in fundamental solutions and digested plant samples were analyzed with an inductively coupled plasma-atomic emission spectrometer (Optima3000, PerkinElmer, Waltham, MA, USA) at the Integrated Center for Sciences, Ehime University, Japan. The linear analytical calibration curves $\left(\mathrm{R}^{2}=0.9999\right.$ for $\mathrm{Zn}, 0.99865$ for $\mathrm{Pb}, 0.99903$ for $\mathrm{Cd}$, and 0.99901 for In) were created from $0,10,100$, and $200 \mu \mathrm{g} / \mathrm{L}$ of $\mathrm{Zn}, \mathrm{Pb}$, and $\mathrm{Cd}$ using $\mathrm{ZnSO}_{4}, \mathrm{PbCl}_{2}$, 
and $\mathrm{CdCl}_{2}$ and from $0,20,100$, and $200 \mu \mathrm{g} / \mathrm{L}$ of $\mathrm{In}$ using $\mathrm{InCl}_{3}$. The detected wavelengths were 205.2, 220.353, 214.440, and $230.606 \mathrm{~nm}$ for $\mathrm{Zn}, \mathrm{Pb}, \mathrm{Cd}$, and In. Fundamental solutions were diluted 50 times for $\mathrm{Zn}$ and 400 times for $\mathrm{Pb}, \mathrm{Cd}$, and In with $3 \% \mathrm{HNO}_{3}$. Digested plant samples were diluted $\sim 25,000$ times for $\mathrm{Zn}$ and $\sim 250,000$ times for $\mathrm{Pb}, \mathrm{Cd}$, and In with 3\% $\mathrm{HNO}_{3}$. The detection limits of $\mathrm{Zn}$, $\mathrm{Pb}, \mathrm{Cd}$, and In in ICP-AES were $0.3,5,0.3$, and $2 \mu \mathrm{g} / \mathrm{L}$, respectively. These values were sufficiently lower than heavy metal concentrations in the sample solutions used in this study.

\subsubsection{Analysis of Si Contents in Plants}

The concentrations of Si were determined using the colorimetric molybdenum blue method [14,15]. The $20 \mathrm{mg}$ pulverized plant powder was digested in a PTFE digestion vessel with $375 \mu \mathrm{L}$ of $35 \% \mathrm{H}_{2} \mathrm{O}_{2}$, $375 \mu \mathrm{L}$ of $61 \% \mathrm{HNO}_{3}$, and $250 \mu \mathrm{L}$ of $48 \% \mathrm{HF}$, and heated on a hotplate at $160{ }^{\circ} \mathrm{C}$ for $30 \mathrm{~min}$ and cooled down at room temperature for $30 \mathrm{~min}$. In the same way, the digesting solution without pulverized plant powder was prepared for standards. Eighty microliters $(80 \mu \mathrm{L})$ of the digested sample was diluted with $920 \mu \mathrm{L}$ of $4 \%$ boric acid. After dilution, $40 \mu \mathrm{L}$ of the diluted solution, $540 \mu \mathrm{L}$ of DIW, $300 \mu \mathrm{L}$ of $0.2 \mathrm{M} \mathrm{HCl}, 40 \mu \mathrm{L}$ of $10 \%\left(\mathrm{NH}_{4}\right)_{6} \mathrm{Mo}_{7} \mathrm{O}_{2}\left(4 \mathrm{H}_{2} \mathrm{O}\right)$, and $40 \mu \mathrm{L}$ of $20 \%$ tartaric acid were added and mixed in turn. After $20 \mathrm{~min}, 40 \mu \mathrm{L}$ of reducing agent $(1 \mathrm{~mL}$ of reducing agent was prepared by dissolving $5 \mathrm{mg}$ of $\mathrm{Na}_{2} \mathrm{SO}_{3}$ and $2.5 \mathrm{mg}$ of 1-amino-2-naphtol-4-sulufonic acid in $970 \mu \mathrm{L}$ of DIW and further dissolving $150 \mathrm{mg} \mathrm{NaHSO}_{3}$ ) was added and mixed. After $1 \mathrm{~h}$, absorbance of $600 \mathrm{~nm}$ and $830 \mathrm{~nm}$ were measured using a spectrophotometer (V-630BIO, JASCO Corp., Tokyo, Japan). The linear analytical calibration curve $\left(R^{2}=0.99541\right.$ at $\left.830 \mathrm{~nm}\right)$ was created from $0,1,5,10$, and $20 \mathrm{mM}$ of $\mathrm{Si}$ using $\mathrm{Na}_{2} \mathrm{SiO}_{3}$. For preparation of diluted solutions for standards, the digesting solution was applied. The detection limit of Si with colorimetric molybdenum blue method was $0.166 \mathrm{mM}$ for $600 \mathrm{~nm}$ or $0.05 \mathrm{mM}$ for $830 \mathrm{~nm}$. The detection limit was sufficiently lower than Si concentrations in the solutions of digested plant materials in this study.

\section{8. $B C F$}

The bioconcentration factor (BCF) provides an index of the ability of a plant to accumulate the metal with respect to the metal concentration in the substrate. The BCF was calculated based on the initial concentration of the given element in the solution as described previously $[10,16]$.

$$
\mathrm{BCF}=\frac{\text { Heavy metal concentration in plants }(\mathrm{mg} / \mathrm{kg} \text { dry weight }(\mathrm{DW}))}{\text { Initial concentration of the heavy metal in the solution }(\mathrm{mg} / \mathrm{L})}
$$

\subsection{Replicates and Statistical Analysis}

All replicates in Figures and Tables were biological replicates. All data analysis was performed in R 3.1.2 with auxiliary packages [17]. We first analyzed distributions of data using Kolmogorov-Smirnov test for confirmation of normal distribution. Then we analyzed the homoscedasticity of data of normal distribution using F-test. The data of non-normal distribution were analyzed using the two-sided Wilcoxon rank sum test as non-parametric test. The data of normal distribution were analyzed using the two-sided Welch t-test for heteroscedasticity of data.

\section{Results}

\subsection{Morphological Features of E. acicularis}

E. acicularis mainly increases its distribution by forming stolons in rivers, ponds, or paddy fields, although it forms seeds in the achenes in terrestrial conditions. Stolons show apical growth and form new ramets at semi-regular intervals (Figure 1a). The new ramet forms a terrestrial stem and roots, thus increasing the number of terrestrial stems and roots. Grown ramets form new stolons (Figure 1b) and increase the number of ramets. 

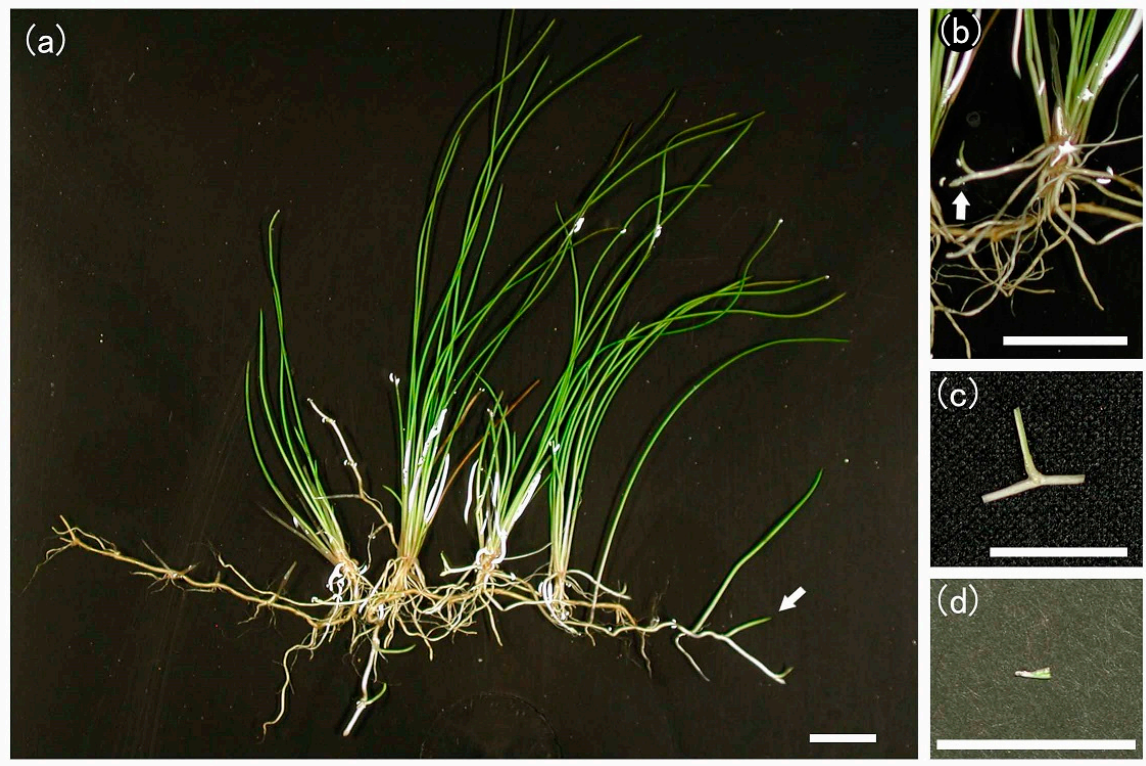

Figure 1. (a) An overview of native E. acicularis. A growing stolon forms a young ramet (white arrow); (b) a new stolon (white arrow) formed from a grown ramet; (c) an explant excised from a young ramet;

(d) an explant excised from a stolon tip. Bar, $10 \mathrm{~mm}$.

\subsection{Establishment of an Aseptic Culture System}

For the practical, aseptic primary culture of E. acicularis, we examined three concentrations of $\mathrm{NaClO}$ for the sterilization of explants and the parts used for explants (Figure 1c,d). Young ramets developing near the stolon tips were excised (Figure 1c), sterilized in $\mathrm{NaClO}(0.15 \%, 0.45 \%$, or $0.75 \%$ of available chlorine), and cultured on solid medium. Figure 2a shows the result of one-week culturing. For a chlorine concentration of $0.75 \%$, we observed a high rate of aseptic and living explants and a low rate of explants contaminated with microbes. Thus, a chlorine concentration of $0.75 \%$ was adopted for subsequent experiments. To verify the suitable parts for explants, we used stolon tips (Figure 1d) in addition to young ramets (Figure $1 \mathrm{c}$ ). Figure $2 \mathrm{~b}$ shows that both stolon tips and young ramets are suitable for primary culture. Figure 2c,d show the explants cultured for 31 days on solid medium. Both stolon tips and young ramets grew developed ramets with many terrestrial stems and roots. Therefore, both stolon tips and young ramets are suitable for primary culture.
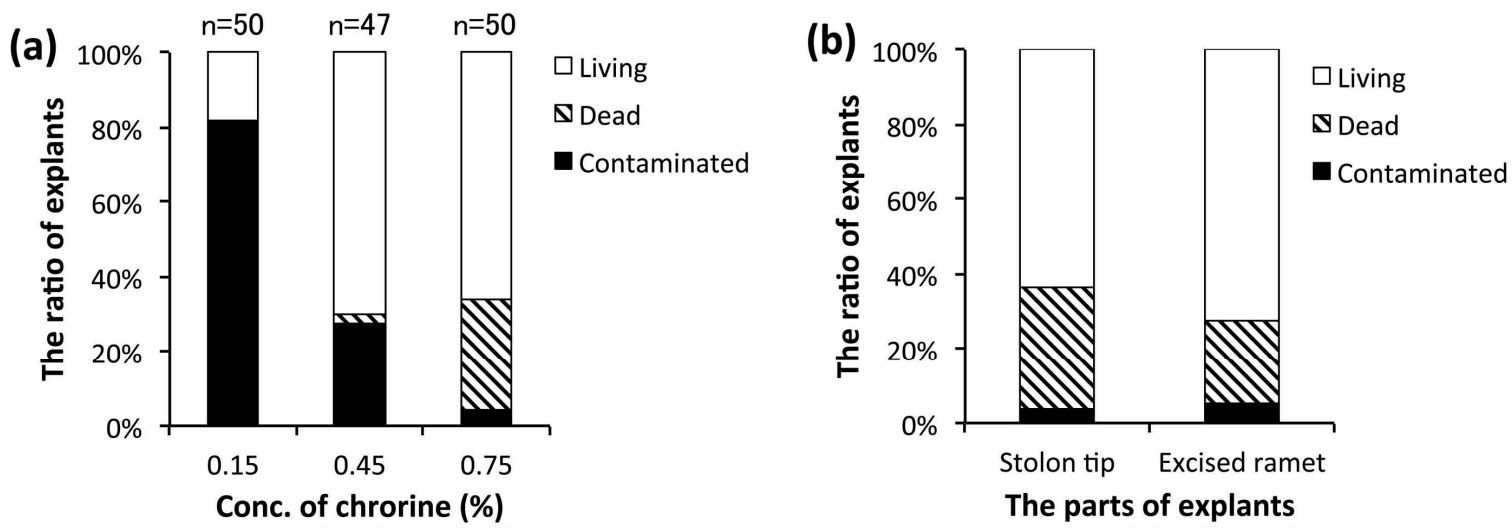

Figure 2. Cont. 

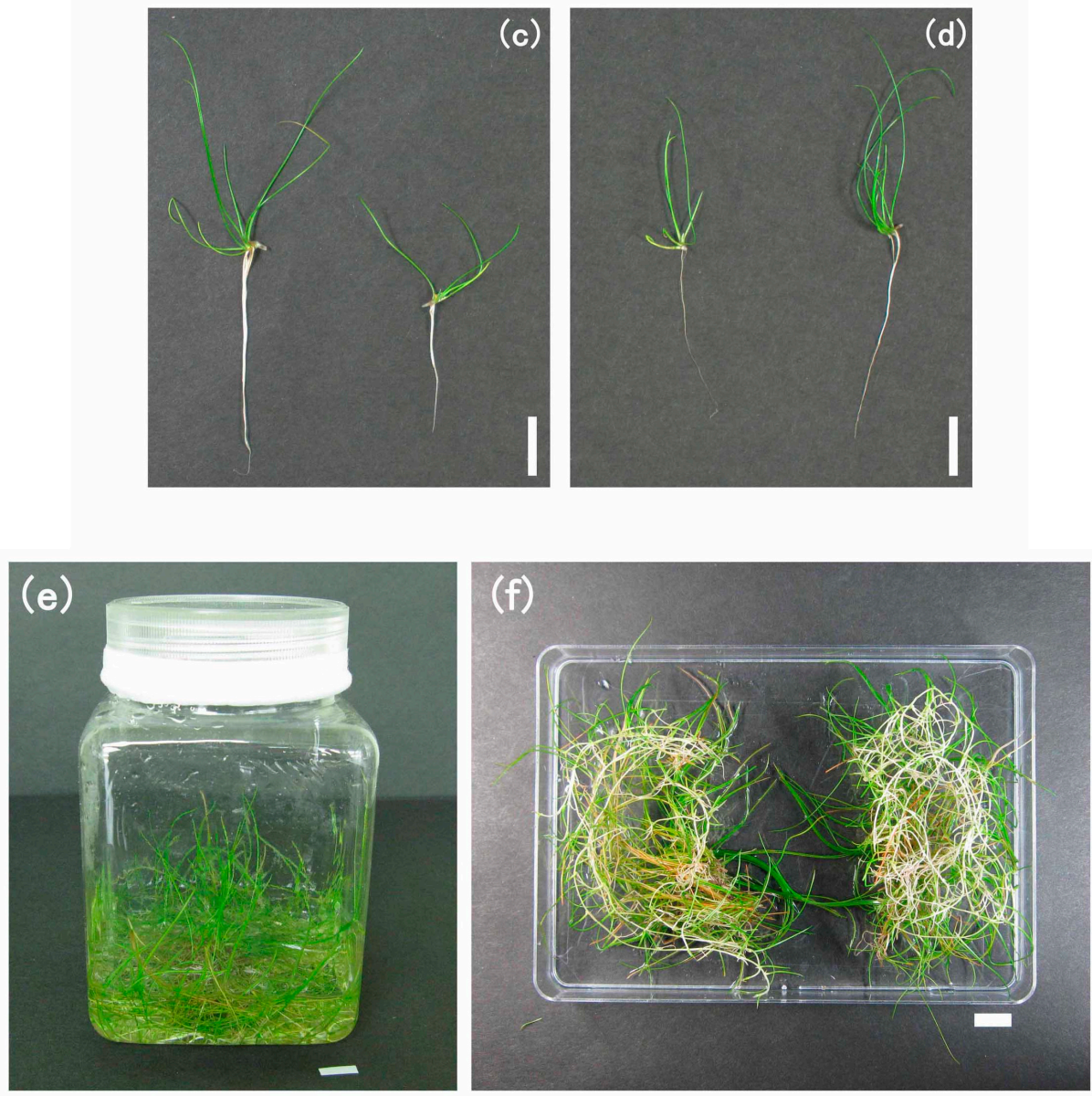

Figure 2. (a) The ratio of explants in three conditions: living, dead, or contaminated with microbes after primary culture. The explants were excised from young ramets and cultured on solid medium for 7 days. The numbers of the replicates are shown in the graph. This result is representative of two experiments. (b) Comparison between explants excised from stolon tips and young ramets for primary culture. The ratio of explants for their conditions, i.e., living, dead, or contaminated with microbes. The explants were cultured on solid medium for 28 days $(n=55)$. (c) Ramets grown from explants of young ramets in 31 days. (d) Ramets grown from explants of stolon tips in 31 days. (e) The plant community was subcultured and grown for 3 weeks in the plastic container. (f) Reversed and divided plant communities grown for 3 weeks after subculturing for the next subculture. Bar $=10 \mathrm{~mm}(\mathbf{c}-\mathbf{f})$.

After growing aseptic plants on solid medium for more than one month, the plants were transferred to liquid medium in a plastic container. After growing fully in the plastic container, plants were divided into two parts. Each part was cultured in a new medium, and grown plants were subcultured once every 3 weeks (Figure 2e,f) as described above. Plant roots usually secrete various acids in the environment. Therefore, we also recorded the change in the $\mathrm{pH}$ of the E. acicularis subculture medium. In this subculture system, the $\mathrm{pH}$ of the medium decreased from 5.7 to $4.1 \pm 0.1$ ( $n=3, \pm$ standard error (SE)) during the culture of E. acicularis for 3 weeks. This system enables plants to grow continuously and allows the permanent use of aseptic plant materials.

\subsection{Analysis of Effective Growth Conditions for Individual Young Ramets}

In this study, we examined the effects of kinetin as cytokinin, $\mathrm{GA}_{3}$ as gibberellin, and NAA as auxin on the growth of isolated young ramets of E. acicularis. These hormones have been used for the promotion of growth in several plants that form stolons $[18,19]$. We studied 64 culture conditions with various combinations of kinetin $(0,0.1,0.5,2.5 \mathrm{mg} / \mathrm{L}), \mathrm{GA}_{3}(0,0.01,0.1,1 \mathrm{mg} / \mathrm{L})$, and NAA 
$(0,0.01,0.1,1 \mathrm{mg} / \mathrm{L})$ for 4 weeks and measured the number of newly formed ramets and the weights of communities formed from a ramet (Figure 3). Kinetin concentrations of 0.1 and $0.5 \mathrm{mg} / \mathrm{L}$ showed an accelerative effect on the number of newly formed ramets. Moreover, 0.1 and $0.5 \mathrm{mg} / \mathrm{L}$ kinetin, 0.1 and/or $1 \mathrm{mg} / \mathrm{L}$ of $\mathrm{GA}_{3}$, and 0.1 and/or $1 \mathrm{mg} / \mathrm{L}$ of NAA showed an accelerative effect on the number of newly formed ramets. The weight of the community formed from a young ramet increased remarkably in response to $0.5 \mathrm{mg} / \mathrm{L}$ of kinetin without $\mathrm{GA}_{3}$ and NAA. However, the addition of $\mathrm{GA}_{3}$ and/or NAA tended to show a suppressive effect on the number of newly formed ramets and the weight of the community formed from a young ramet in the absence of kinetin. Considering the remarkable accelerative effect of kinetin, we used it independently in further experiments.

(a)
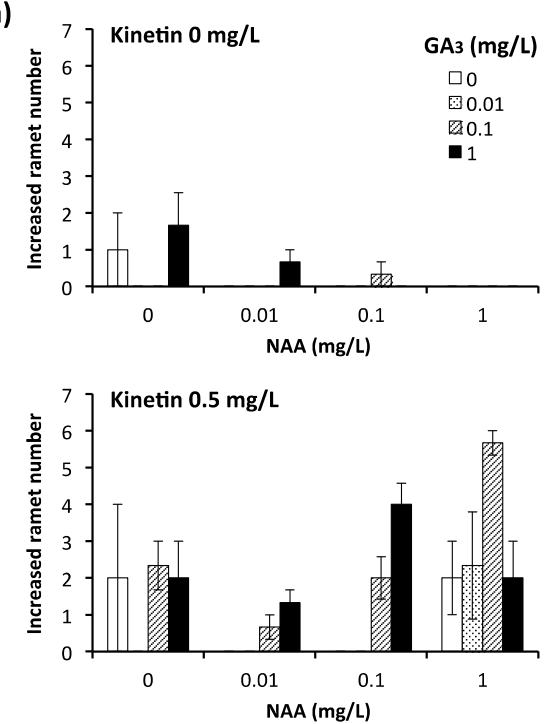

(b)
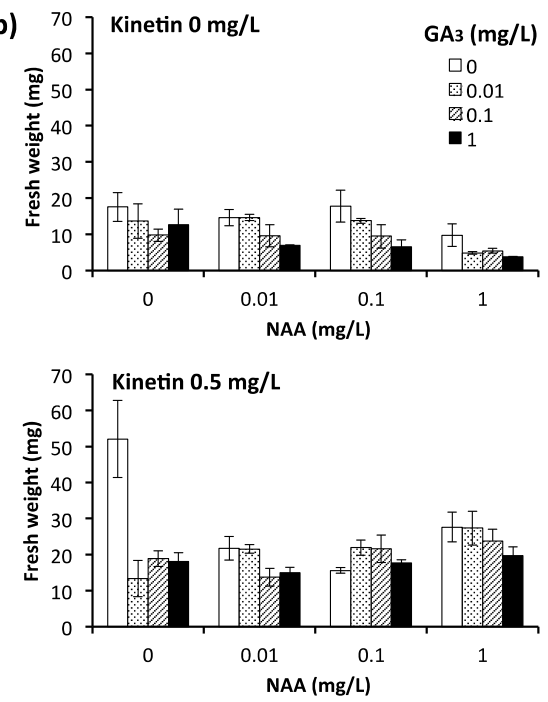
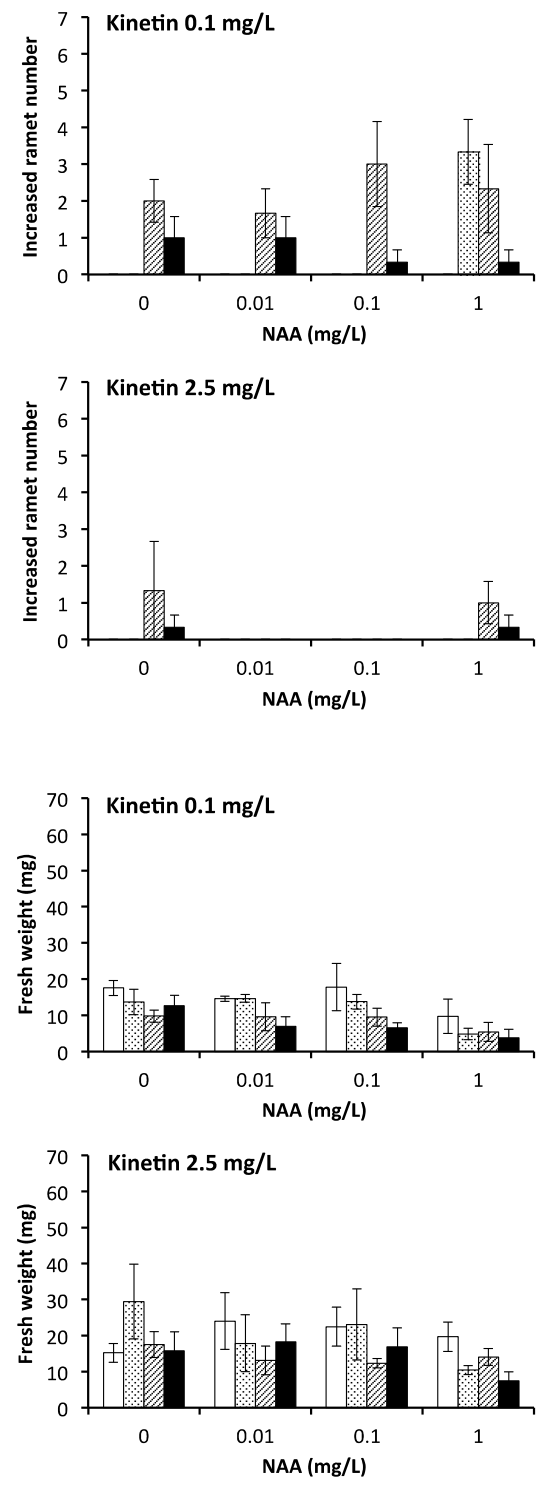

Figure 3. The number of newly formed ramets from a young isolated ramet (a) and the fresh weight of newly formed communities from a young isolated ramet $(\mathbf{b})$ in 4 weeks at various concentrations of kinetin $(0,0.1,0.5,2.5 \mathrm{mg} / \mathrm{L})$, gibberellic acid-3 $\left(\mathrm{GA}_{3}\right)(0,0.01,0.1,1 \mathrm{mg} / \mathrm{L})$, and 1-naphthaleneacetic acid (NAA) $(0,0.01,0.1,1 \mathrm{mg} / \mathrm{L})(n=3$, Bar: standard error (SE)). These results were representatives of three experiments.

Next, we examined the growth of isolated young ramets of E. acicularis in response to $\mathrm{pH}$ of the liquid medium in addition to the concentration of kinetin. Figure $4 a, b$ show the effect of various 
concentrations of kinetin on the increase in ramet number and weight at $\mathrm{pH}$ 5.1, 5.4, and 5.7. For all $\mathrm{pH}$ values, a concentration of $0.25 \mathrm{mg} / \mathrm{L}$ kinetin showed a significant accelerative effect on both the number of ramets and the weight of communities. Thus, $0.25 \mathrm{mg} / \mathrm{L}$ of kinetin is the most suitable concentration for the growth of isolated single ramets. Figure $4 \mathrm{c}, \mathrm{d}$ show the effect of the $\mathrm{pH}$ range of 4.2 to 6.3 in the absence and presence of $0.25 \mathrm{mg} / \mathrm{L}$ of kinetin. In the absence of kinetin, the number of newly formed ramets was 2 or below for all $\mathrm{pH}$ values. On the other hand, the addition of $0.25 \mathrm{mg} / \mathrm{L}$ kinetin showed clear accelerative effects on both the number of newly formed ramets and the weight of communities in a $\mathrm{pH}$ range of 4.8 to 5.7. Under those conditions, the number of newly formed ramets was four and above, and the communities were nearly twice as heavy as the communities without kinetin. These results showed that $0.25 \mathrm{mg} / \mathrm{L}$ of kinetin and a $\mathrm{pH}$ range of 4.8 to 5.7 are the most suitable conditions for the growth of isolated young ramets of E. acicularis.
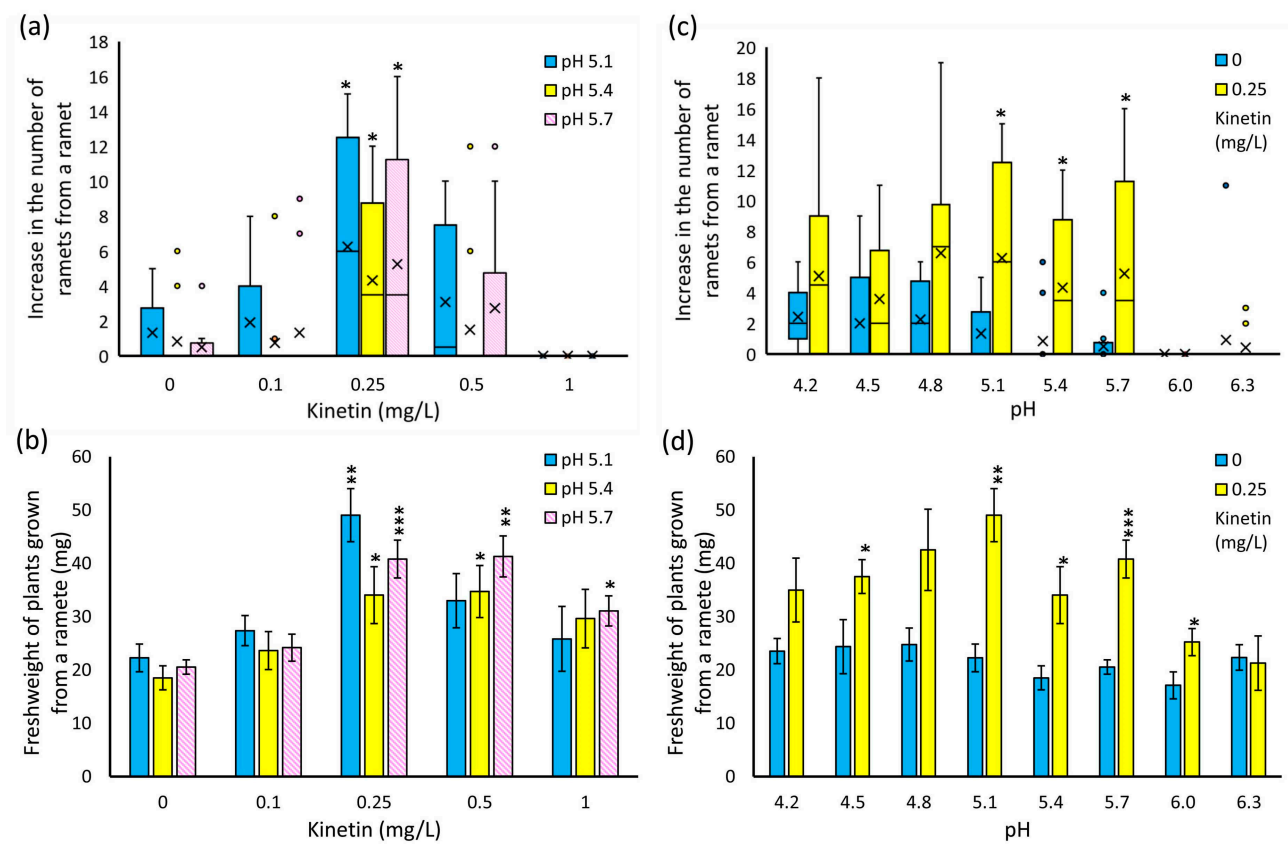

(e)

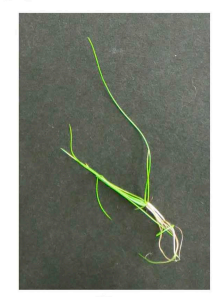

0

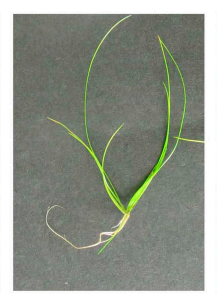

0.1

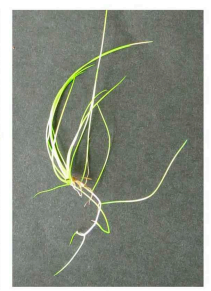

0.25

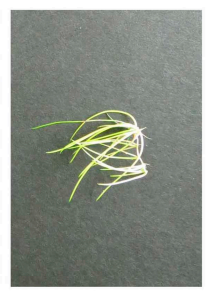

0.5

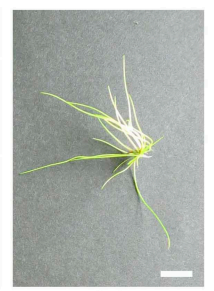

1.0

Kinetin (mg/L)

Figure 4. Effects of various concentrations of kinetin and various $\mathrm{pH}$ ranges on the growth of ramets $(\mathbf{a}, \mathbf{b}, \mathbf{c}, \mathbf{d})$. The number of newly formed ramets from a young isolated ramet (box plot, $\mathrm{X}$ indicates average, $n=12)(\mathbf{a}, \mathbf{c})$ and the weight of newly formed plants from a young isolated ramet (bar graph, $n=12$, Bar: SE) (b,d) in 4 weeks at various concentrations of kinetin $(0,0.1,0.25,0.5,1 \mathrm{mg} / \mathrm{L})$ and three $\mathrm{pH}$ values $(5.1,5.4,5.7)(\mathbf{a}, \mathbf{b})$ or in the absence or presence of kinetin $(0.25 \mathrm{mg} / \mathrm{L})$ and various $\mathrm{pH}$ values (4.2 to 6.3) (c,d). Asterisks indicate significant differences from the value of $0 \mathrm{mg} / \mathrm{L}$ kinetin under the same $\mathrm{pH}$ (two-sided Wilcoxon rank sum test; $(\mathbf{a}, \mathbf{c})$ two-sided Welch $t$-test; $(\mathbf{b}, \mathbf{d}){ }^{*} p<0.05$; ${ }^{* *} p<0.01 ; * * *<0.001$ ). (e) Plants grown from a young, isolated ramet cultured for 4 weeks in various concentrations of kinetin at $\mathrm{pH}$ 5.7. These results were representatives of two experiments. 


\subsection{Heavy Metal Accumulation}

The aseptically cultured E. acicularis plants were exposed to heavy metals to evaluate their accumulation potential. Monocotyledons such as Poaceae and Cyperaceae frequently accumulate silicon as "plant opals", also known as phytoliths. We also examined whether silicon addition during subculture is effective for heavy metal accumulation. We used two types of plants subcultured either in the absence or in the presence of $0.1 \mathrm{mM} \mathrm{Na}_{2} \mathrm{SiO}_{3}$. The plants supplied with $\mathrm{Si}$ showed phytoliths under a light microscope (Figure 5a,b). These plants were further exposed to approximately $4.8 \mathrm{mg} / \mathrm{L} \mathrm{Cs}$, and the concentration of Cs in the solution decreased steadily (Figure 5c). The decreased Cs was effectively accumulated for 28 days by both plants subcultured with or without of $0.1 \mathrm{mM}$ of $\mathrm{Si}$ (Figure $5 \mathrm{~d}$ ). Cs accumulations were $2782 \pm 48$ and $2248 \pm 99 \mathrm{mg} / \mathrm{kg}$ DW in $-\mathrm{Si}$ and $+\mathrm{Si}$ E. acicularis, respectively.

(a)

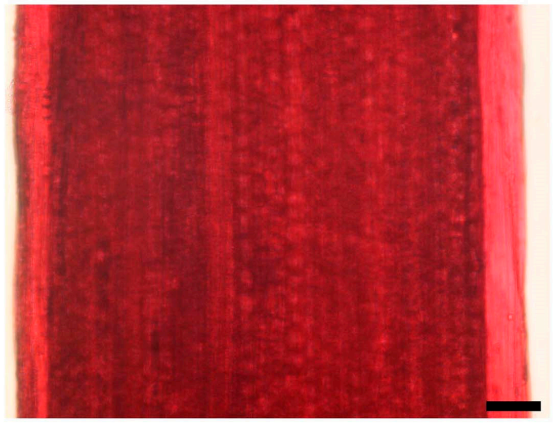

(c)

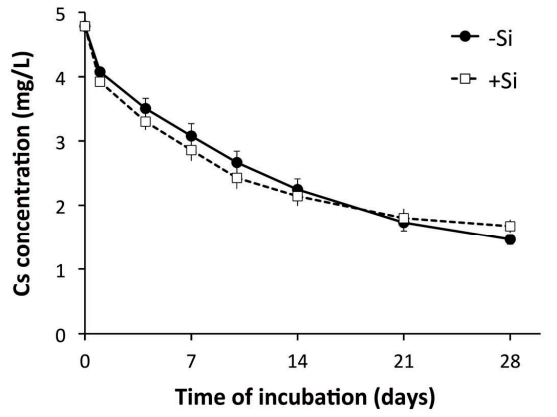

(b)

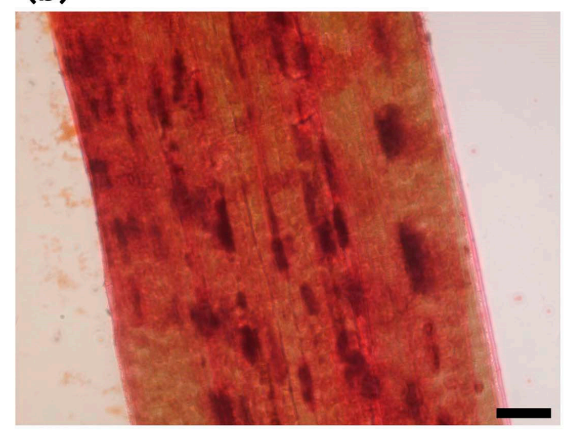

(d)

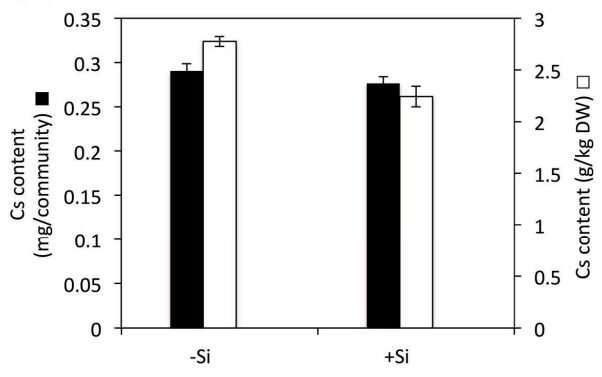

Figure 5. Staining of phytoliths in E. acicularis without (a) or with (b) $0.1 \mathrm{mM}$ Si during subculture. Bar $=50 \mu \mathrm{m}$; (c) The decrease in Cs concentration in the solution containing plants subcultured without or with $0.1 \mathrm{mM} \mathrm{Si}(n=3$, Bar, SE). This result is representative of two similar experiments. (d) Accumulation of Cs in plant communities after 4 weeks of incubation of (c) ( $n=3$, Bar, SE). The results of $(\mathbf{c}, \mathbf{d})$ were measured by inductively coupled plasma-mass spectrometry (ICP-MS).

Furthermore, we added $1 \mathrm{mM}$ of $\mathrm{Si}$ during subculture to confirm the effect of higher concentrations of Si. The plants subcultured in the presence of $1 \mathrm{mM} \mathrm{Na}_{2} \mathrm{SiO}_{3}$ showed the presence of phytoliths (Figure 6a,b) and the accumulation of Si (Figure 6c). Moreover, Cs was accumulated in plants regardless of the presence or absence of Si (Figure 6d). 
(a)

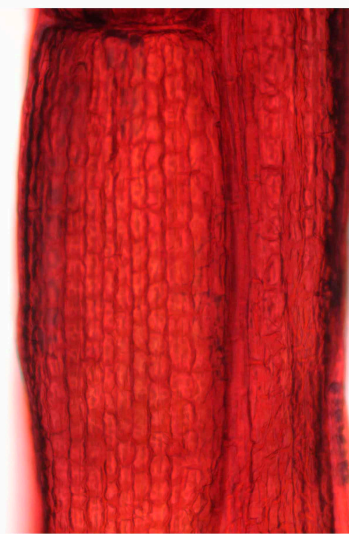

(c)

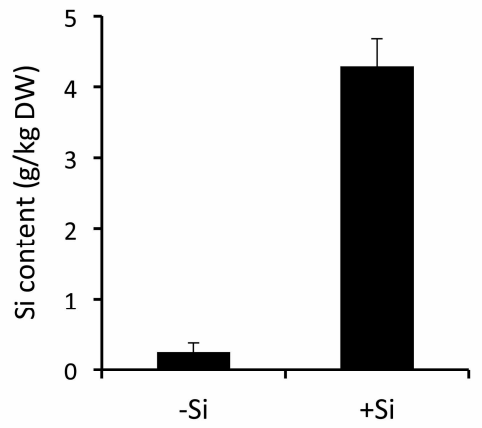

(b)

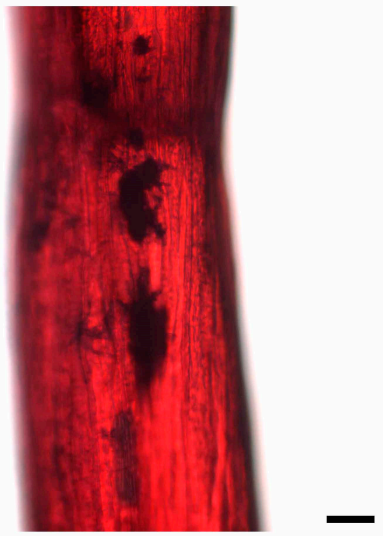

(d)

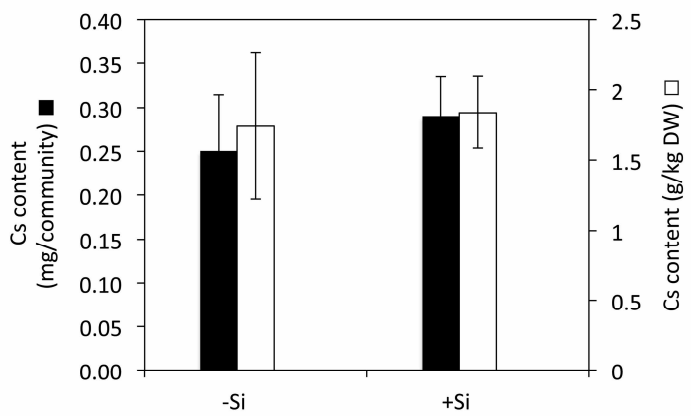

Figure 6. Staining of phytoliths in E. acicularis without (a) or with (b) $1 \mathrm{mM}$ Si during subculture. Bar $=50 \mu \mathrm{m}$. (c) The determination of Si contents in E. acicularis subcultured with or without $1 \mathrm{mM} \mathrm{Si}$ ( $n=3$, Bar, SE). (d) Accumulation of Cs in plant communities incubated in $4.8 \mathrm{mg} / \mathrm{L}$ Cs solutions $(n=3$, Bar, SE). Plant communities were subcultured with or without $1 \mathrm{mM} \mathrm{Si}$ and used for the experiment of Cs accumulation. Contents of Cs were determined with atomic absorption photometer. (c,d) These results were representatives of two experiments.

Using the plants subcultured with or without of $1 \mathrm{mM} \mathrm{Si}$, we investigated the accumulation of heavy metals from the solution with approximate concentrations of $4 \mathrm{mg} / \mathrm{L} \mathrm{Zn,} 41 \mathrm{mg} / \mathrm{L} \mathrm{Pb}, 47 \mathrm{mg} / \mathrm{L}$ $\mathrm{Cd}$, or $38 \mathrm{mg} / \mathrm{L}$ In for 14 days (Figure 7). The concentrations of these heavy metals were selected according to the previous reports using E. acicularis [6] and our other experiments to estimate the ability of heavy metal accumulation. In addition, the duration of 2 weeks to expose plants to these heavy metals was selected to estimate minimum capacity of heavy metal accumulation based on the result of Cs removal from the basal solution (Figure 5) that changes in the Cs concentration were prominent in first 2 weeks. $\mathrm{Zn}, \mathrm{Pb}, \mathrm{Cd}$, and In were continuously removed from the solutions for two weeks (Figure 7a) and effectively accumulated in plants both in the presence and absence of $\mathrm{Si}$ (Figure 7b). 
(a)
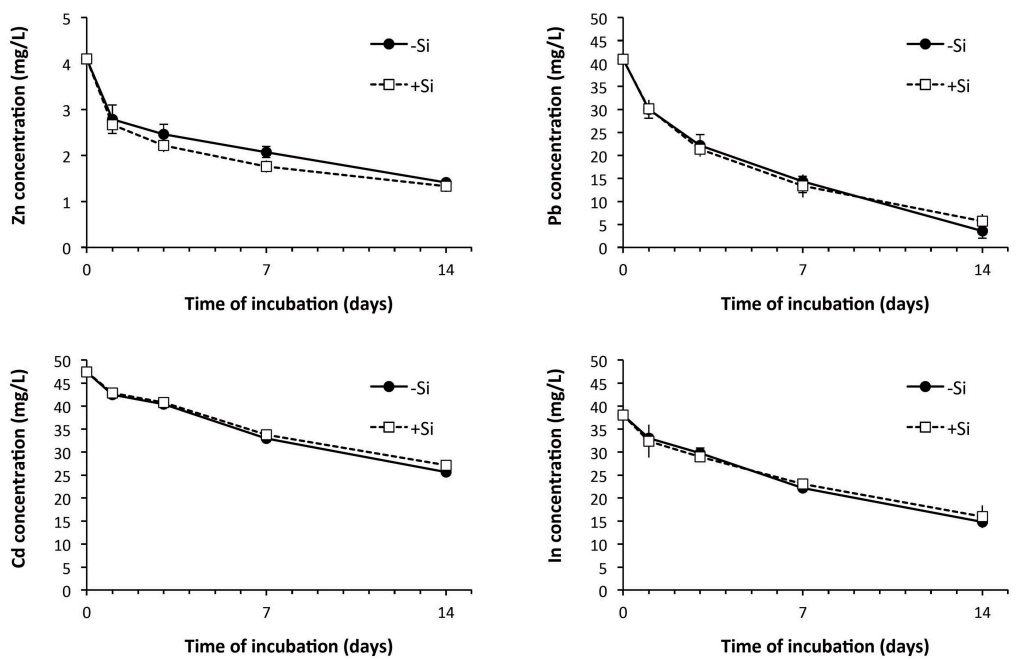

(b)
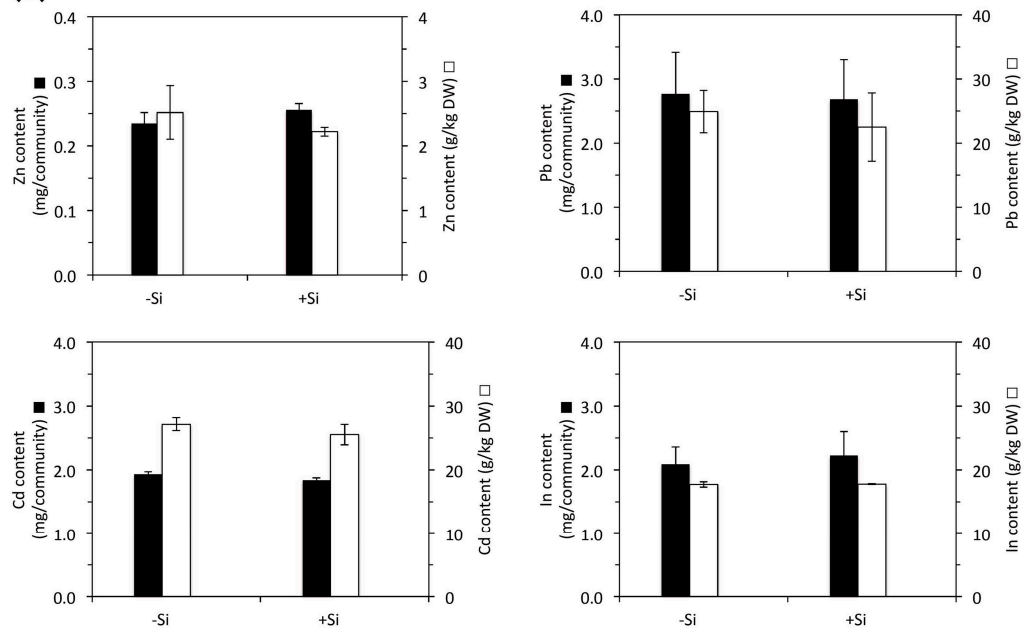

Figure 7. (a) Decrease of $\mathrm{Zn}, \mathrm{Pb}, \mathrm{Cd}$, and In concentrations in the solution containing plants subcultured with or without $1 \mathrm{mM} \mathrm{Si}(n=2$, Bar, SE). (b) Accumulation of $\mathrm{Zn}, \mathrm{Pb}, \mathrm{Cd}$, and In in plant communities incubated with the solution of each heavy metal ( $n=2$, Bar, SE). Plants were subcultured in the medium with or without $1 \mathrm{mM} \mathrm{Si}$. The results of $(\mathbf{a}, \mathbf{b})$ were measured by inductively coupled plasma-atomic emission spectroscopy (ICP-AES). These results were representatives of two similar experiments.

Table 1 summarizes the results of heavy metal removal and accumulation in E. acicularis with or without $\mathrm{Si}$ addition during subculture. Table 2 showed the basal contents of $\mathrm{Cs}, \mathrm{Zn}, \mathrm{Pb}, \mathrm{Cd}$, and $\mathrm{In}$ in aseptically cultured E. acicularis. Although the basal content of Zn was $149 \mathrm{mg} / \mathrm{kg}$ DW because of $\mathrm{Zn}$ as the trace element of culture medium [11], the basal contents of $\mathrm{Cs}, \mathrm{Pb}, \mathrm{Cd}$, and $\mathrm{In}$ were $0.3 \%$ or lower than those in E. acicularis after accumulation of these heavy metals in Table 1. Accumulation rates for $\mathrm{Cs}, \mathrm{Zn}, \mathrm{Pb}, \mathrm{Cd}$, and In were 73.5 to $100.1 \%$ regardless of $\mathrm{Si}$ addition or subtraction during subculture (Table 1). In several conditions, accumulation rates were lower than $100 \%$. This would be caused by precipitation of heavy metals, removal of adsorbed heavy metals by washing the plants with DIW, and/or adsorption to plastic containers during incubation. The BCF values for $\mathrm{Cs}, \mathrm{Zn}, \mathrm{Pb}$, $\mathrm{Cd}$, and In were 468 to 613 regardless of $\mathrm{Si}$ addition or subtraction during subculture. These results clearly indicate that $E$. acicularis cultured in aseptic conditions has a sufficient ability to accumulate the heavy metals $\mathrm{Cs}, \mathrm{Zn}, \mathrm{Pb}, \mathrm{Cd}$, and In with or without the addition of $\mathrm{Si}$ during subculture. 
Table 1. Summary of the removal of heavy metals and accumulation in E. acicularis subcultured with or without $\mathrm{Si}$. BCF, bioconcentration factor.

\begin{tabular}{|c|c|c|c|c|c|c|c|c|}
\hline $\begin{array}{l}\text { Heavy } \\
\text { Metal }\end{array}$ & $\begin{array}{c}\text { Initial } \\
\text { Conc. of } \\
\text { Fundamental } \\
\text { Solution } \\
(\mathrm{mg} / \mathrm{L})\end{array}$ & $\begin{array}{l}\text { Si Conc. } \\
(\mathrm{mM})\end{array}$ & $\begin{array}{l}\text { Incubation } \\
\text { Period (d) }\end{array}$ & $\begin{array}{c}\text { Heavy Metal } \\
\text { Removal } \\
\text { (mg/L } \\
\text { Solution) }\end{array}$ & $\begin{array}{l}\text { DW of Whole } \\
\text { Plants after } \\
\text { Incubation } \\
\text { (mg/L } \\
\text { Solution) }\end{array}$ & $\begin{array}{l}\text { Heavy Metal } \\
\text { Accumulation } \\
\text { in Whole } \\
\text { Plants } \\
\text { (mg/kg DW) }\end{array}$ & $\begin{array}{l}\text { Accumulation } \\
\text { Rate (\%) } \\
\text { (Accumulation } \\
\text { in Whole } \\
\text { Plants/ } \\
\text { Removal from } \\
\text { Solution) }\end{array}$ & BCF \\
\hline Cs & $4.79 \pm 0.02$ & $\begin{array}{c}0 \\
0.1\end{array}$ & 28 & $\begin{array}{l}3.32 \pm 0.10 \\
3.11 \pm 0.12\end{array}$ & $\begin{array}{l}1046 \pm 25 \\
1234 \pm 25\end{array}$ & $\begin{array}{l}2782 \pm 48 \\
2248 \pm 99\end{array}$ & $\begin{array}{l}87.6 \pm 0.7 \\
89.1 \pm 1.1\end{array}$ & $\begin{array}{l}581 \pm 10 \\
470 \pm 21\end{array}$ \\
\hline $\mathrm{Zn}$ & $4.10 \pm 0.04$ & $\begin{array}{l}0 \\
1\end{array}$ & 14 & $\begin{array}{l}2.69 \pm 0.06 \\
2.77 \pm 0.12 \\
\end{array}$ & $\begin{array}{l}970 \pm 228 \\
1152 \pm 11\end{array}$ & $\begin{array}{c}2517 \pm 414 \\
2219 \pm 69\end{array}$ & $\begin{array}{l}87.0 \pm 4.3 \\
92.1 \pm 0.2\end{array}$ & $\begin{array}{c}613 \pm 101 \\
541 \pm 17\end{array}$ \\
\hline $\mathrm{Pb}$ & $40.89 \pm 0.29$ & $\begin{array}{l}0 \\
1\end{array}$ & 14 & $\begin{array}{l}37.35 \pm 1.44 \\
35.21 \pm 1.54\end{array}$ & $\begin{array}{c}1097 \pm 116 \\
1196 \pm 9\end{array}$ & $\begin{array}{l}24885 \pm 3293 \\
22486 \pm 5320\end{array}$ & $\begin{array}{l}73.5 \pm 14.5 \\
75.6 \pm 14.2\end{array}$ & $\begin{array}{c}609 \pm 81 \\
550 \pm 130\end{array}$ \\
\hline $\mathrm{Cd}$ & $47.40 \pm 0.21$ & $\begin{array}{l}0 \\
1\end{array}$ & 14 & $\begin{array}{l}21.75 \pm 0.24 \\
20.25 \pm 0.25\end{array}$ & $\begin{array}{l}713 \pm 12 \\
722 \pm 30\end{array}$ & $\begin{array}{l}27153 \pm 1017 \\
25556 \pm 1613\end{array}$ & $\begin{array}{l}88.9 \pm 0.9 \\
90.9 \pm 3.1\end{array}$ & $\begin{array}{l}573 \pm 21 \\
539 \pm 34\end{array}$ \\
\hline
\end{tabular}

Table 2. Basal contents of heavy metals in aseptically cultured E. acicularis. These results were measured with ICP-MS. Dry weight to $10 \mathrm{~g}$ fresh weight was $750 \pm 52 \mathrm{mg}(n=2, \pm \mathrm{SE})$.

\begin{tabular}{cccccc}
\hline Heavy Metal & Cs & Zn & Pb & Cd & In \\
\hline Content $(\mathrm{mg} / \mathrm{kg} \mathrm{DW})$ & $6.12 \pm 0.60$ & $148.5 \pm 0.17$ & $0.36 \pm 0.16$ & $0.15 \pm 0.09$ & $0.02 \pm 0.00$ \\
\hline
\end{tabular}

\section{Discussion}

\subsection{Primary Culture and Subculture Conditions}

The stolon tips and basal parts of young ramets in E. acicularis are suitable materials for primary culture because they are viable and have a small size for the easy removal of microorganisms by sterilization. We collected native E. acicularis for primary culture in the field from April to early June because it grows well in spring and early summer and provides growing stolons that are suitable for primary culture. In the subculture system of E. acicularis, we could continuously multiply E. acicularis eight times in nine weeks in any season and area because of its doubling time of three weeks.

\subsection{Growth Conditions for Young Ramets}

This study showed that $0.25 \mathrm{mg} / \mathrm{L}$ kinetin and a $\mathrm{pH}$ of 4.8 to 5.7 are effective growth conditions for young ramets of E. acicularis (Figure 4). Although $\mathrm{GA}_{3}$ and NAA were effective in increasing the number of ramets only in the presence of 0.1 or $0.5 \mathrm{mg} / \mathrm{L}$ of kinetin (Figure 3a), $\mathrm{GA}_{3}$ and NAA suppressed their growth in the absence of kinetin (Figure 3b). Gibberellin has an elongation effect, but the extra application of gibberellin results in excessive elongation, as shown in the legginess of Oryza sativa due to infection with the fungus Gibberella fujikuroi (Sawada) W. [20]. The application of increased auxin results in enhanced root formation [21]. Cytokinin induces the formation of the shoot apical meristems and the growth of shoots [22]. Therefore, the application of an appropriate concentration of kinetin was thought to show a positive effect on newly formed ramets and to increase the number of stems. As kinetin is a natural product formed by the degradation of DNA [23], it would be better than unnatural cytokinins for the environment when aseptically cultured E. acicularis is applied in the field. The suitable $\mathrm{pH}$ for effective growth was a weakly acidic $\mathrm{pH}$ of 4.8 to 5.7. Eleocharis acicularis was suggested to secrete protons and organic acids such as mugineic acid in the soil environment [24]. In this subculture system, the $\mathrm{pH}$ of the medium decreased from 5.7 to 4.1 during 21 days of subculture. E. acicularis would adjust to an ambient $\mathrm{pH}$ suitable for its growth by the secretion of various acids. E. equisetina, of the same genus, is resistant to an acid environment 
of $\mathrm{pH} 2.45$ and accumulates various heavy metals [25]. In E. acicularis, the secreted acid would also contribute to the effective accumulation of heavy metals via ionization.

\subsection{Heavy Metal Accumulation}

\subsubsection{Cesium}

Native E. acicularis has been shown to accumulate radioactive Cs (i.e., ${ }^{134} \mathrm{Cs}$ and ${ }^{137} \mathrm{Cs}$ ) in a paddy field contaminated with radioactive Cs caused by the Fukushima Daiichi nuclear disaster [8]. Cs was also accumulated effectively by aseptically cultured E. acicularis (Table 1, Figures 5 and 6). In this study, $2782 \mathrm{mg} / \mathrm{kg}$ DW of Cs accumulated in E. acicularis in 28 days. Although the threshold concentration of Cs in hyperaccumulators has not been suggested previously, $2782 \mathrm{mg} / \mathrm{kg}$ DW Cs in E. acicularis in this study is not widely different from $420 \mathrm{mg} / \mathrm{kg}$ fresh weight of Cs in the shoots of Brassica juncea grown for 21 days in $8.24 \mathrm{mg} / \mathrm{L}$ Cs solution [26]. Brassica juncea has been reported as a hyperaccumulator plant for the accumulation of several heavy metals [27]. These results are consistent with the hypothesis that aseptically cultured E. acicularis might have great potential for the removal of radioactive Cs from the nuclear disaster area.

\subsubsection{Effect of Aseptic Culture of E. acicularis on Accumulation of $\mathrm{Zn}, \mathrm{Pb}, \mathrm{Cd}$, and In}

$\mathrm{Zn}$ accumulation was reported as $2517 \mathrm{mg} / \mathrm{kg}$ DW in aseptically cultured E. acicularis for 14 days. This value was lower than the $10000 \mathrm{mg} / \mathrm{kg}$ DW threshold concentration of $\mathrm{Zn}$ in a hyperaccumulator [28]. However, it was considerably higher than past laboratory experiments using native E. acicularis, (i.e., $600 \mathrm{mg} / \mathrm{kg}$ DW [4], $93 \mathrm{mg} / \mathrm{kg}$ DW [5] and $213 \mathrm{mg} / \mathrm{kg}$ DW [6] in the shoots of E. acicularis).

$\mathrm{Pb}$ accumulation for 14 days was $24885 \mathrm{mg} / \mathrm{kg}$ DW in aseptically cultured E. acicularis. This value was higher than $1000 \mathrm{mg} / \mathrm{kg} \mathrm{DW}$, the threshold concentration of $\mathrm{Pb}$ in hyperaccumulators [28]. Furthermore, it was 22 times higher than past laboratory experiments using native E. acicularis (i.e., $1110 \mathrm{mg} / \mathrm{kg}$ DW [4] and $1120 \mathrm{mg} / \mathrm{kg}$ DW [6] in the shoots of E. acicularis).

Cd accumulation was reported as $27153 \mathrm{mg} / \mathrm{kg}$ DW in aseptically cultured E. acicularis for 14 days. This value was remarkably higher than $100 \mathrm{mg} / \mathrm{kg}$ DW, the threshold concentration of Cd in a hyperaccumulator [28]. Furthermore, it was 139 times higher than the past laboratory observation of $195 \mathrm{mg} / \mathrm{kg}$ DW [6] in the shoots of native E. acicularis.

Indium accumulation was reported to be $17737 \mathrm{mg} / \mathrm{kg}$ DW in aseptically cultured E. acicularis in 14 days. This value was higher than $100 \mathrm{mg} / \mathrm{kg} \mathrm{DW}$, the threshold concentration of In in a hyperaccumulator [6]. Furthermore, it was 50 times higher than the past laboratory experiments of $353 \mathrm{mg} / \mathrm{kg}$ DW [6] in shoots of native E. acicularis.

$\mathrm{Ha}$ et al. [6] used a mixture of $\mathrm{In}, \mathrm{Ag}, \mathrm{Pb}, \mathrm{Cu}, \mathrm{Cd}$, and $\mathrm{Zn}$ in solution and measured their accumulation in native E. acicularis after 15 days of culture. The total amounts of heavy metals accumulated in the shoots of native E. acicularis after 15 days of culture were 2202 to $2324 \mathrm{mg} / \mathrm{kg}$ DW. Each amount of $2517 \mathrm{mg} / \mathrm{kg}$ DW of Zn, 24,885 mg/kg DW of Pb, 27,153 mg/kg DW of Cd, and $17,737 \mathrm{mg} / \mathrm{kg}$ DW of In accumulated in aseptically cultured E. acicularis was higher than the total accumulation of heavy metals of 2202 to $2324 \mathrm{mg} / \mathrm{kg}$ DW in the shoots of native E. acicularis in Ha et al. [6]. Although it is difficult to compare these two results based on different experimental conditions, these findings indicate that the aseptic culture of E. acicularis enhances its native capacity for the accumulation of heavy metals. The growth of aseptically cultured plants is not disturbed by biotic and abiotic stressors. On the contrary, it could be stimulated by plant hormones. Moreover, the exposure to the heavy metals in "in vitro" conditions is very high and not affected by environmental factors. After this, "ex vitro" testing is required to truly evaluate the phytoremediation ability of the plants that at this stage can be only considered as potential. 


\subsubsection{Effect of Silicon Addition during Subculture of E. acicularis on Heavy Metal Accumulation}

Accumulation of heavy metals (i.e., $\mathrm{Cs}, \mathrm{Zn}, \mathrm{Pb}, \mathrm{Cd}$, and In) in - $\mathrm{Si}$ plants was the same as in $+\mathrm{Si}$ plants (Figures 5-7, Table 1), indicating that the addition of Si during subculture is not necessary for the accumulation of these heavy metals in E. acicularis. The localizations of these heavy metals in the cells are various. Cs was indicated to be absorbed by a K transporter [29] and was localized with $\mathrm{K}$ in Arabidopsis [30]. Zn was indicated to localize mainly in the vacuole [31]. $\mathrm{Pb}$ and $\mathrm{Cd}$ were mainly localized in the vacuole and cell wall [32]. The localization of In in plant cells was not shown. Si was shown to alleviate heavy metal toxicity in various plants [33]. In some plants, Si has been reported to form complexes and to co-precipitate with heavy metals in different plant parts. The effect of Si on heavy metal accumulation in E. acicularis for phytoremediation remains to be determined.

\section{Conclusions}

In conclusion, in this study, we established an aseptic culture system for E. acicularis. This system enabled E. acicularis to enhance its native capacity for the accumulation of heavy metals by the exclusion of biotic and abiotic factors in the field and by the supply of appropriate growth conditions. This system is efficient for analyzing the heavy metal accumulation mechanism in E. acicularis and its contribution to phytoremediation. This study also showed that $\mathrm{Si}$ addition during the subculture of E. acicularis is not necessary for heavy metal accumulation.

Acknowledgments: We thank Makoto Kuramoto (Ehime University) for his assistance in ICP-AES analysis, and Masahiro Inouhe and Kazuho Nohara (Ehime University) for their assistance in atomic absorption spectrophotometry analysis. This work was supported in part by JSPS KAKENHI (Grant Number 24540492 and 16H02706) and Adaptable and Seamless Technology Transfer Program through target-driven R\&D to M.S.

Author Contributions: Yasushi Sato and Masayuki Sakakibara designed the project. Yasushi Sato, Shinpei Goto, Shoya Teraoka, and Katsuya Takagaki carried out most of the experiments. Akinari Takehara contributed to the ICP-MS and ICP-AES analysis. Sakae Sano contributed to the ICP-MS analysis. Yasushi Sato and Masayuki Sakakibara wrote the article.

Conflicts of Interest: The authors declare no conflict of interest.

\section{References}

1. Ali, H.; Khan, E.; Sajad, M.A. Phytoremediation of heavy metals-concepts and applications. Chemosphere 2013, 91, 869-881. [CrossRef] [PubMed]

2. Khalid, S.; Shahid, M.; Niazi, N.K.; Murartaza, B.; Bibi, I.; Dumat, C. A comparison of technologies for remediation of heavy metal contaminated soils. J. Geochem. Explor. 2016. [CrossRef]

3. Gomes, M.A.; Hauser-Davis, R.A.; de Souza, A.N.; Vitória, A.P. Metal phytoremediation: General strategies, genetically modified plants and applications in metal nanoparticle contamination. Ecotoxicol. Environ. Saf. 2016, 134, 133-147. [CrossRef] [PubMed]

4. Ha, N.T.H.; Sakakibara, M.; Sano, S.; Hori, R.S.; Sera, K. The potential of Eleocharis acicularis for phytoremediation: Case study at an abandoned mine site. Clean 2009, 37, 203-208.

5. Ha, N.T.H.; Sakakibara, M.; Sano, S. Phytoremediation of Sb, As, Cu, and $\mathrm{Zn}$ from contaminated water by the aquatic macrophyte Eleocharis acicularis. Clean 2009, 37, 720-725. [CrossRef]

6. Ha, N.T.H.; Sakakibara, M.; Sano, S. Accumulation of Indium and other heavy metals by Eleocharis acicularis: An option for phytoremediation and phytomining. Bioresour. Technol. 2011, 102, 2228-2234. [CrossRef] [PubMed]

7. Sakakibara, M.; Ohmori, Y.; Ha, N.T.H.; Sano, S.; Sera, K. Phytoremediation of heavy metal-contaminated water and sediment by Eleocharis acicularis. Clean 2011, 39, 735-741. [CrossRef]

8. Sakakibara, M.; Sato, Y.; Sano, S.; Kubota, Y. Radioactive concentration of radioactive cesium of native Eleocharis acicularis in paddy fields of Fukushima Prefecture, northeastern Japan. J. Soc. Remediat. Radioact. Contam. Environ. 2014, 2, 13-18.

9. Chekroun, K.B.; Baghour, M. The role of algae in phytoremediation of heavy metals: A review. J. Mater. Environ. Sci. 2013, 4, 873-880. 
10. Rezania, S.; Taib, S.M.; Din, M.F.M.; Dahalan, F.A.; Kamyab, H. Comprehensive review on phytotechnology: Heavy metals removal by diverse aquatic plants species from wastewater. J. Hazard. Mater. 2016, 318, 587-599. [CrossRef] [PubMed]

11. Murashige, T.; Skoog, F. A revised medium for rapid growth and bio assays with tobacco tissue cultures. Physiol. Plant. 1962, 15, 473-497. [CrossRef]

12. Dayanandan, P.; Kaufman, P.B.; Franklin, C.I. Detection of silica in plants. Am. J. Bot. 1983, 70, 1079-1084. [CrossRef]

13. Sueoka, Y.; Sakakibara, M.; Sano, S.; Yamamoto, Y. A new method of environmental assessment and monitoring of $\mathrm{Cu}, \mathrm{Zn}, \mathrm{As}$, and $\mathrm{Pb}$ pollution in surface soil using terricolous fruticose lichens. Environments 2016, 3, 35. [CrossRef]

14. Ma, J.F.; Yamaji, N.; Tamai, K.; Mitani, N. Genotypic difference in silicon uptake and expression of silicon transporter genes in rice. Plant Physiol. 2007, 145, 919-924. [CrossRef] [PubMed]

15. Okuda, A.; Takahashi, E. Studies on the physiological role of silicon in crop plants: 1. Discussion on the silicon deficient culture method. J. Sci. Soil Manure Jpn. 1961, 32, 475-480.

16. Kara, Y.; Zeytunluoglu, A. Bioaccumulation of Toxic Metals (Cd and Cu) by Groenlandia densa (L.) Fourr. Bull. Environ. Contam. Toxicol. 2007, 79, 609-612. [CrossRef] [PubMed]

17. R Core Team. R: A Language and Environment for Statistical Computing; R Foundation for Statistical Computing: Vienna, Austria, 2017.

18. Binth, L.T.; Muoi, L.T.; Oanh, H.T.K.; Thang, T.D.; Phong, D.T. Rapid propagation of agave by in vitro tissue culture. Plant Cell Tissue Organ Cult. 1990, 23, 67-70. [CrossRef]

19. Kojoma, M.; Ohyama, K.; Seki, H.; Hiraoka, Y.; Asazu, S.A.; Sawa, S.; Sekizaki, H.; Yoshida, S.; Muranaka, T. In vitro proliferation and triterpenoid characteristics of licorice (Glycyrrhiza uralensis Fischer, Leguminosae) stolons. Plant Biotechnol. 2010, 27, 56-66. [CrossRef]

20. Hedden, P.; Spontel, V. A century of gibberellin research. J. Plant Growth Regul. 2015, 34, 740-760. [CrossRef] [PubMed]

21. Saini, S.; Sharma, I.; Kaur, N.; Pati, P.K. Auxin: A master regulator in plant root development. Plant Cell Rep. 2013, 32, 741-757. [CrossRef] [PubMed]

22. Howell, S.H.; Lall, S.; Che, P. Cytokinins and shoot development. Trends Plant Sci. 2003, 8, 453-459. [CrossRef]

23. Miller, C.O.; Skoog, F.; Saltza, M.H.V.; Strong, F.M. Kinetin, a cell division factor from deoxyribonucleic acid. J. Am. Chem. Soc. 1955, 77, 1392. [CrossRef]

24. Takehara, A.; Nishiwaki, H.; Sato, Y.; Sakakibara, M. Roles of organic acids released by aquatic macrophyte Eleocharis acicularis. In Proceedings of the International Conference of Transdisciplinary Research on Environmental Problem in Southeastern Asia (TREPSEA), Makassar, Indonesia, 4-5 September 2014; pp. 85-88.

25. Lottermoser, B.G.; Ashley, P.M. Trace element uptake by Eleocharis equisetina (spike rush) in an abandoned acid mine tailings pond, northeastern Australia: Implications for land and water reclamation in tropical regions. Environ. Pollut. 2011, 159, 3028-3035. [CrossRef] [PubMed]

26. Fu, Q.; Lai, J.L.; Tao, Z.Y.; Han, N.; Wu, G. Characterizations of bio-accumulations, subcellular distribution and chemical forms of cesium in Brassica juncea, and Vicia faba. J. Environ. Radioact. 2016, 154, 52-59. [CrossRef] [PubMed]

27. John, R.; Ahmad, P.; Gadgil, K.; Sharma, S. Heavy metal toxicity: Effect on plant growth, biochemical parameters and metal accumulation by Brassica juncea L. Int. J. Plant Prod. 2009, 3, 65-76.

28. Baker, A.J.M.; Brooks, R.R. Terrestrial higher plants which hyper accumulate metallic elements-A review of their distribution, ecology, and phytochemistry. Biorecovery 1989, 1, 81-126.

29. Kobayashi, D.; Uozumi, N.; Hisamatsu, S.; Yamagami, M. AtKUP/HAK/KT9, a K+ transporter from Arabidopsis thaliana, mediates $\mathrm{Cs}^{+}$uptake in Escherichia coli. Biosci. Biotechnol. Biochem. 2010, 74, $203-205$. [CrossRef] [PubMed]

30. Isaure, M.-P.; Fraysse, A.; Devès, G.; Le Lay, P.; Fayard, B.; Susini, J.; Bourguignon, J.; Ortega, R. Micro-chemical imaging of cesium distribution in Arabidopsis thaliana plant and its interaction with potassium and essential trace elements. Biochimie 2006, 88, 1583-1590. [CrossRef] [PubMed]

31. Broadley, M.R.; White, P.J.; Hammond, J.P.; Zelko, I.; Lux, A. Zinc in plants. New Phytol. 2007, 173, 677-702. [CrossRef] [PubMed] 
32. Seregin, I.V.; Kozhevnikova, A.D. Roles of root and shoot tissues in transport and accumulation of cadmium, lead, nickel, and strontium. Russ. J. Plant Physiol. 2008, 55, 1-22. [CrossRef]

33. Adrees, M.; Ali, S.; Rizwan, M.; Zia-ur-Rehman, M.; Ibrahim, M.; Abbas, F.; Farid, M.; Qayyum, M.F.; Irshad, M.K. Mechanisms of silicon-mediated alleviation of heavy metal toxicity in plants: A review. Ecotoxicol. Environ. Saf. 2015, 119, 186-197. [CrossRef] [PubMed] 